Dwi Setyo Astuti, Ruslan. (2019). Analisis Tingkat Kemiripan Orthoptera Menggunakan Indeks Sorensen dan Dendogram di Hutan Bromo Karanganyar Jawa Tengah, Indonesia. Jurnal Bioeksperimen. Vol. 5 (1) Pp. 39-47. Doi: 10.23917/bioeksperimen.v5i1.2795

\title{
ANALISIS TINGKAT KEMIRIPAN ORTHOPTERA MENGGUNAKAN INDEKS SORENSEN DAN DENDOGRAM DI HUTAN BROMO KARANGANYAR JAWA TENGAH, INDONESIA
}

\author{
${ }^{1 *}$ Dwi Setyo Astuti; ${ }^{2}$ Ruslan \\ Program Studi Pendidikan Biologi Fakultas Keguruan dan Ilmu Pendidikan \\ ${ }^{1)}$ Universitas Muhammadiyah Surakarta \\ Jl. Ahmad Yani Tromol Pos I Pabelan Kartasura Surakarta, Jawa Tengah, Indonesia \\ ${ }^{2)}$ Dinas Pertanian Perkebunan dan Perikanan Kabupaten Blora, Jawa Timur, Indonesia \\ *Email: dsa122@ums.ac.id
}

\begin{abstract}
Abstrak
Identifikasi suatu spesies dilakukan dengan cara mengamati berbagai ciri umum maupun khusus dari spesies tersebut berdasarkan karakter morfologi. Tujuan penelitian ini adalah untuk mengidentifikasi dan menghitung tingkat kekerabatan Ordo Orthoptera di Hutan Wisata Bromo Karanganyar menggunakan indeks kesamaan Sorensen dan dendogram. Metode penelitian menggunakan deskriptif kuantitatif. Sampel diperoleh melalui sampling di beberapa etape dalam hutan meliputi semak, jalan setapak, sungai dan area pepohonan. Hasil menunjukan bahwa dari 10 spesies yang diperoleh, Melanoplus differentialis dan Melanoplus bivitatus memiliki kekerabatan paling dekat yaitu sebesar 92,3\% sedangkan kekerabatan paling jauh adalah antara Melanoplus differentialis dan Neocurtila hexadactila yaitu sebesar 33,87\%. Spesies dalam satu tingkatan takson yang sama cenderung memiliki kemiripan morfologi yang tinggi dibanding dengan spesies dari takson yang berbeda, meski beberapa spesies tidak menunjukkan hal demikian.
\end{abstract}

Kata kunci: Orthoptera, Indeks Sorensen, Dendogram, Tingkat Kekerabatan, Melanoplus differentialis

\begin{abstract}
Species identification was conducted by observing various general and specific characteristics of the species based on morphological characters. The purpose of this study was to identify and calculate the level of Orthoptera order in the forest of Bromo Karanganyar by using the similirity index of Sorensen and dendogram. This research method used the descriptive and quantitative data. Samples obtained from several locations in the forest including shrubs, trails, rivers and tree areas. The results showed that the 10 species obtained, Melanoplus differentialis and Melanoplus bivitatus had the closest phylogenetic that is equal to 92.3\%. However the farthest phylogenetic are Melanoplus differentialis and Neocurtila hexadactila which are $33.87 \%$. Species in the same level of taxon tend to have high morphological similarities compared to species from different taxon, although some species are not exist.
\end{abstract}

Keywords: Orthoptera, Sorensen Index, Dendogram, Phylogenetic, Melanoplus differentialis

\section{Pendahuluan}

Serangga merupakan kelompok Arthropoda yang memiliki sebaran paling luas di bumi (Jordan, et al., 2015). Habitat serangga mencakup daratan hingga perairan dan sebagian kecil di laut (Craig \& Bock, 2009). Serangga atau yang lebih dikenal dengan nama Insecta ini terbagi sedikitnya kedalam 17 ordo berdasarkan sifat sayap, kondisi dimiliki. Diantara sekian banyak anggota Insecta, terdapat 1 ordo yang memiliki sebaran paling luas, yaitu Orthoptera. Ortoptera memiliki pola persebaran secara ekologi (Bidau, 2014 ). Ciri khusus Orthoptera adalah memiliki bentuk sayap yang lurus, mulut tipe penggigit, dan mengalami metamorfosis tidak sempurna (Falahudin, Mareta, \& Rahayu, 2015).

Klasifikasi Orthoptera kedalam beberapa takson berdasarkan atas beberapa karakter meliputi anatomi, fisiologi, ekologi, dan morfologi. Karakter morfologi merupakan yang paling banyak digunakan untuk membagi spesies kedalam takson yang sesuai dengan kekerabatan atau filogeni (Jayashree \& Channaveerappa, 2016 
); (Wrueng, Tan, Artchawakom, \& Waengsothorn, 2017). Untuk menarik kesimpulan tentang filogeni, para ahli sistematika harus mengumpulkan informasi mengenai morfologi, gen, dan biokimia dari berbagai organisme yang relevan. Penting untuk berfokus pada ciri-ciri yang merupakan hasil dari nenek moyang bersama, karena hanya ciri-ciri inilah yang merefleksikan hubungan evolusioner (Hojun Song, Ricardo Mariño-Pérez, A. Woller, \& Marta Cigliano, 2018).

Sebagian besar pembagian kingdom hewan berdasarkan morfologi, simetri, metameri, fisiologi, dan pola perkembangan caelom. Tipe pembelahan dalam telur juga banyak dibahas sebagai dasar menentukan kekerabatan. Selanjutnya pola kekerabatan spesies dapat dengan jelas dilihat dari suatu diagram dendogram. Dendogram menggambarkan proses pembentukan klaster yang dinyatakan dalam bentuk gambar dan persen. Garis mendatar di atas dendogram menunjukkan prosentase yang menggambarkan tingkat kemiripan, semakin besar prosentase yang dimiliki menunjukkan semakin mirip individu tersebut. Dendogram yang digunakan untuk menera tingkat kemiripan pada serangga (Dinakaran \& Anbalagan, 2007).

Untuk menentukan tingkat kekerabatan ordo Orthoptera maka hal pertama yang perlu dilakukan adalah mengambil sampel spesies dari habitat asli, seperti alam terbuka, semak-semak, area persawahan, dan atau hutan (Horchkirch, 1996). Salah satu area yang menjadi habitat alami dari Orthoptera adalah gunung Bromo Karanganyar. Gunung Bromo merupakan salah satu kekayaan wisata di Kabupaten Karanganyar letaknya kurang lebih $5 \mathrm{~km}$ ke arah utara Kota Karanganyar. Kawasan hutan penelitian yang ditumbuhi berbagai jenis pohon, termasuk pohon-pohon langka, seperti cendana. Selain itu hal yang paling menarik adalah dalam kawasan hutan ini terdapat sejenis pohon yang tidak hanya langka tetapi juga khas, yaitu pohon kayu jati yang tumbuh dikelilingi oleh pohon-pohon beringin, dikenal dengan nama "Jati Kurung.

Komplek Gunung Bromo merupakan wana wisata harian dengan luas wilayah 115 hektar yang menawarkan objek wisata berupa hutan wisata, petilasan dan area bermain anak. Gunung Bromo terletak pada ketinggian 400 meter dengan topografi tanah bergelombang
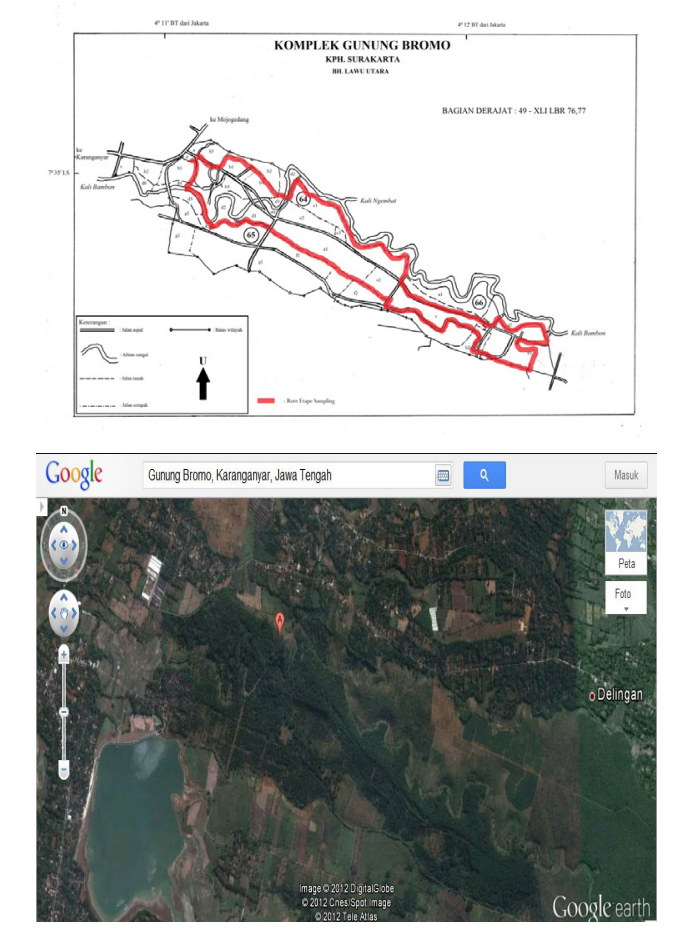

Gambar 1. Citra satelit komplek Gunung Bromo

Temperatur udara di Wana Wisata Gunung Bromo berkisar antara $15-25^{\circ} \mathrm{C}$ dengan curah hujan tergolong tinggi yaitu $\pm 3.712 \mathrm{~mm} /$ tahun . Fungsi Gunung Bromo selain untuk pariwisata juga merupakan hutan produksi dengan vegetasi tanaman pinus, mahoni dan Sonokeling (Lestari, Putri, Ridwan, \& Purwaningsih, 2015).

\section{Material dan Metode}

Penelitian dilakukan bulan November 2018. Penangkapan sampel dan pengambilan spesimen Orthoptera dilakukan di komplek Gunung Bromo Kabupaten Karanganyar, Jawa Tengah, Indonesia. Proses identifikasi, determinasi, pengawetan dan perhitungan kekerabatan spesimen dilakukan di Laboratorium Pendidikan Biologi Fakultas Keguruan dan Ilmu Pendidikan Universitas Muhammadiyah Surakarta.

Alat insect net dengan diameter $50 \mathrm{~cm}$, termohigrometer, teropong binokular luxmeter, kamera digital Canon EOS 1000D 10 Megapixel + lensa kit untuk dokumentasi. Bahan yang digunakan adalah $300 \mathrm{ml}$. 


\section{Prosedur Pelaksanaan Penelitian}

Penelitian ini menggunakan metode deskriptif kuantitatif. Hasil deskripsi dari identifikasi digunakan sebagai dasar perhitungan kekerabatan spesies menggunakan rumus indeks kesamaan Sorensen sebagai berikut :

$$
S=\frac{2 C}{A+B} X 100 \%
$$

Keterangan :

$S$ : Indeks kesamaan

A : Jumlah karakter yang dimiliki oleh spesies A.

B : Jumlah karakter yang dimiliki oleh spesies B.

C : Jumlah karakter yang sama yang dimiliki oleh spesies A dan B.

\section{Teknik Pengumpulan Data}

Data diperoleh melalui metode sampling di beberapa etape di dalam hutan meliputi area semak, jalan setapak, sekitar sungai dan pepohonan yang tinggi. Sampling dilakukan setiap pagi dan sore selama 2 hari. Semua spesies hasil tangkapan diidentifikasi karakter morfologi yang dimiliki untuk selanjutnya dihitung indeks kesamaannya.

Tingkat kekerabatan akan diperoleh setelah membandingkan indeks kesamaan antar spesies. Prosentase kekerabatan spesies kemudian disajikan dalam suatu dendogram yang akan memperlihatkan titik simpang dimana spesies-spesies dalam satu tingkatan takson bertemu dan berpisah berdasarkan kemiripan.

\section{Analisis dan Interpretasi Data}

Penelitian ini terdiri atas beberapa data yaitu: 1) hasil identifikasi karakter morfologi setiap spesies, 2) hasil perhitungan kesamaan ciri menggunakan rumus indeks Sorensen, 3) prosentase kekerabatan antar spesies, 4) interpretasi hasil berupa diagram dendogram.

\section{Hasil dan Pembahasan}

\section{Spesies Hasil Tangkap}

Berdasarkan penangkapan yang dilakukan, ditemukan 10 spesies Orthoptera yang berasal dari 4 familia, yaitu Acrididae, Tettigonidae, Gryllotalpidea ,dan Mantodae .

Tabel 1. Spesies hasil tangkap

\begin{tabular}{cll}
\hline No & \multicolumn{1}{c}{ Nama Spesies } & \multicolumn{1}{c}{ Familia } \\
\hline 1 & Gesonula mundata & Acrididae \\
2 & Valanga nigricornis & Acrididae \\
3 & Neoconocephalus ensiger & Tettigonidae \\
4 & Melanoplus differentialis & Acrididae \\
5 & Melanoplus bivitatus & Acrididae \\
6 & Neocurtila hexadactila & Gryllotalpidea \\
7 & Stagmomantis carolina & Mantodae \\
8 & Euthystira brachyptera & Acrididae \\
9 & Acrida conica & Acrididae \\
10 & Amblycoripha oblongifolia & Tettigonidae \\
\hline
\end{tabular}

\section{Identifikasi Spesies}

Spesies yang telah ditangkap selanjutnya diidentifikasi karakter morfologi yang dimiliki. Jika suatu spesies memiliki karakter sebagaimana tercantum dalam tabel identifikasi, maka dinotasikan dengan angka 1. Jika suatu spesies tidak memiliki ciri seperti yang disebutkan dalam tabel, maka dinotasikan dengan angka 0 .

Tabel 2. Identifikasi karakter morfologi setiap spesies

\begin{tabular}{|c|c|c|c|c|c|c|c|c|c|c|c|}
\hline \multirow[t]{2}{*}{ No } & \multirow{2}{*}{ Karakter / ciri yang Diamati } & \multicolumn{10}{|c|}{$\begin{array}{c}\text { Variasi Karakter / ciri } \\
\text { (dalam spesies yang sama) }\end{array}$} \\
\hline & & 1 & 2 & 3 & 4 & 5 & 6 & 7 & 8 & 9 & 10 \\
\hline 1 & Femur kaki belakang jelas lebih besar daripada femur kaki depan & 1 & 1 & 1 & 1 & 1 & 1 & 1 & 1 & 1 & 1 \\
\hline 2 & Femur kaki belakang tidak jelas lebih besar daripada femur kaki depan & 1 & 0 & 0 & 1 & 1 & 0 & 0 & 1 & 1 & 0 \\
\hline 3 & Antenna sama panjang atau lebih panjang dari seluruh tubuh & 0 & 1 & 0 & 0 & 0 & 0 & 0 & 0 & 0 & 0 \\
\hline 4 & $\begin{array}{l}\text { Antenna panjangnya kira-kira separuh atau lebih pendek dari panjang } \\
\text { seluruh tubuh }\end{array}$ & 1 & 1 & 1 & 1 & 1 & 0 & 0 & 0 & 0 & 0 \\
\hline 5 & Tarsi 3 ruas & 0 & 0 & 0 & 0 & 0 & 1 & 0 & 0 & 1 & 0 \\
\hline 6 & Tarsi 4 ruas & 0 & 0 & 0 & 0 & 1 & 0 & 0 & 0 & 0 & 1 \\
\hline
\end{tabular}




\begin{tabular}{|c|c|c|c|c|c|c|c|c|c|c|c|}
\hline \multirow[t]{2}{*}{ No } & \multirow[t]{2}{*}{ Karakter / ciri yang Diamati } & \multicolumn{10}{|c|}{$\begin{array}{c}\text { Variasi Karakter / ciri } \\
\text { (dalam spesies yang sama) }\end{array}$} \\
\hline & & 1 & 2 & 3 & 4 & 5 & 6 & 7 & 8 & 9 & 10 \\
\hline 7 & Ovipositor panjang seperti jarum & 0 & 0 & 0 & 0 & 0 & 0 & 1 & 0 & 0 & 0 \\
\hline 8 & Ovipositor panjang seperti pedang & 0 & 0 & 0 & 1 & 0 & 0 & 1 & 0 & 0 & 1 \\
\hline 9 & Ovipositor pendek & 1 & 0 & 1 & 0 & 0 & 0 & 1 & 0 & 0 & 1 \\
\hline 10 & Tibia kaki depan membesar, digunakan untuk menggali & 1 & 1 & 0 & 0 & 0 & 0 & 1 & 0 & 0 & 0 \\
\hline 11 & Tibia kaki depan mengecil & 1 & 0 & 0 & 0 & 0 & 0 & 1 & 0 & 0 & 0 \\
\hline 12 & tubuh besar dan memanjang & 0 & 1 & 1 & 1 & 1 & 1 & 1 & 1 & 0 & 1 \\
\hline 13 & Tubuh kecil dan memanjang & 1 & 0 & 0 & 0 & 0 & 0 & 0 & 0 & 1 & 0 \\
\hline 14 & Kaki depan berfungsi untuk memegangi mangsa & 0 & 0 & 1 & 1 & 0 & 0 & 0 & 1 & 0 & 1 \\
\hline 15 & Kaki depan tidak untuk memegangi mangsa & 1 & 1 & 0 & 0 & 1 & 1 & 1 & 0 & 1 & 1 \\
\hline 16 & Femur bergerigi menyerupai duri & 0 & 1 & 0 & 0 & 0 & 1 & 1 & 0 & 1 & 0 \\
\hline 17 & Femur tidak bergerigi / rata & 1 & 0 & 1 & 1 & 1 & 0 & 0 & 1 & 0 & 0 \\
\hline 18 & Badan pipih memanjang menyerupai bentuk daun & 0 & 1 & 1 & 1 & 1 & 1 & 1 & 1 & 1 & 1 \\
\hline 19 & Badan pipih memanjang menyerupai bentuk ranting & 1 & 0 & 0 & 0 & 0 & 0 & 0 & 0 & 0 & 0 \\
\hline 20 & Badan oval, tebal dan tampak keras & 0 & 1 & 1 & 1 & 1 & 1 & 0 & 1 & 1 & 1 \\
\hline 21 & Warna tubuh dan sayap sama & 1 & 0 & 0 & 0 & 0 & 0 & 1 & 0 & 0 & 0 \\
\hline 22 & Warna tubuh dan sayap berbeda & 0 & 0 & 0 & 0 & 0 & 1 & 0 & 1 & 0 & 0 \\
\hline 23 & Warna tubuh cenderung cokelat tidak mengkilap & 1 & 1 & 0 & 0 & 1 & 0 & 1 & 0 & 0 & 1 \\
\hline 24 & Warna tubuh cenderung cokelat mengkilap & 0 & 0 & 1 & 1 & 0 & 0 & 0 & 0 & 1 & 0 \\
\hline 25 & Warna tubuh cenderung hijau & 0 & 1 & 1 & 1 & 0 & 0 & 0 & 1 & 1 & 0 \\
\hline 26 & Bentuk kepala oval & 0 & 0 & 0 & 0 & 0 & 1 & 0 & 0 & 0 & 1 \\
\hline 27 & Bentuk kepala membulat & 0 & 0 & 1 & 0 & 0 & 0 & 0 & 1 & 0 & 0 \\
\hline 28 & Bentuk kepala segitiga & 0 & 0 & 0 & 0 & 1 & 0 & 1 & 0 & 0 & 1 \\
\hline 29 & Bentuk kepala lancip & 1 & 1 & 1 & 1 & 0 & 1 & 0 & 1 & 1 & 0 \\
\hline 30 & Kepala bersembunyi dibalik pronotum & 1 & 1 & 0 & 0 & 1 & 1 & 1 & 0 & 1 & 0 \\
\hline 31 & Memiliki alat suara yang terletak di ruas abdomen pertama & 0 & 0 & 1 & 1 & 0 & 0 & 0 & 1 & 0 & 0 \\
\hline 32 & Tidak memiliki alat suara & 1 & 0 & 0 & 0 & 0 & 0 & 0 & 1 & 0 & \\
\hline 33 & Pronotum memanjang ke belakang & 0 & 1 & 1 & 1 & 0 & 1 & 1 & 1 & 0 & 1 \\
\hline 34 & Pronotum tidak memanjang ke belakang & 0 & 1 & 0 & 0 & 1 & 1 & 1 & 1 & 1 & 0 \\
\hline 35 & Antenna berambut & 1 & 1 & 0 & 0 & 0 & 1 & 1 & 1 & 1 & 0 \\
\hline 36 & Antena tidak berambut & 0 & 0 & 1 & 1 & 1 & 0 & 0 & 0 & 0 & 1 \\
\hline 37 & Memiliki prothorax yang panjang & 1 & 1 & 0 & 0 & 1 & 1 & 1 & 0 & 0 & 0 \\
\hline 38 & Prothorax pendek atau tidak memiliki prothorax & 0 & 0 & 1 & 1 & 0 & 0 & 0 & 1 & 1 & 1 \\
\hline & Jumlah Karakter & 17 & 17 & 16 & 16 & 15 & 15 & 18 & 17 & 15 & 15 \\
\hline
\end{tabular}

3. Perhitungan Indeks Kesamaan Sorensen Jumlah karakter total yang berhasil diidentifikasi dari masing-masing spesies dikonversi menjadi numerik untuk dihitung dan ditabulasikan dalam matriks. Setiap spesies dihitung prosentase kemiripannya menggunakan rumus Sorensen. Berikut adalah matriks perhitungan kemiripan antar spesies: 
Tabel 3. Perolehan perhitungan tingkat kemiripan morfologi dalam persen semua species

\begin{tabular}{|c|c|c|c|c|c|c|c|c|c|c|c|}
\hline$*$ & 1 & 2 & 3 & 4 & 5 & 6 & 7 & 8 & 9 & 10 & Max \\
\hline 1 & $*$ & $57,14 \%$ & $\begin{array}{c}41,38 \\
\%\end{array}$ & $\begin{array}{c}55,56 \\
\%\end{array}$ & $\begin{array}{c}61,54 \\
\%\end{array}$ & $24 \%$ & $\begin{array}{c}33,33 \\
\%\end{array}$ & $\begin{array}{c}52,92 \\
\%\end{array}$ & $\begin{array}{c}72,22 \\
\%\end{array}$ & $\begin{array}{c}32,26 \\
\%\end{array}$ & $\begin{array}{c}72,22 \\
\%\end{array}$ \\
\hline 2 & & * & $\begin{array}{c}33,7 \\
\%\end{array}$ & $\begin{array}{c}91,4 \\
\%\end{array}$ & $84,2 \%$ & $48,3 \%$ & $54,5 \%$ & $62,9 \%$ & $25 \%$ & $66,7 \%$ & $91,4 \%$ \\
\hline 3 & & & $*$ & $\begin{array}{c}34,5 \\
\%\end{array}$ & $\begin{array}{c}31,3 \\
\%\end{array}$ & $44,4 \%$ & $43,5 \%$ & $\begin{array}{c}14,8 \\
\%\end{array}$ & $\begin{array}{c}41,4 \\
\%\end{array}$ & $66,7 \%$ & $66,7 \%$ \\
\hline 4 & & & & $*$ & $\begin{array}{c}92,3 \\
\%\end{array}$ & $24 \%$ & $46,7 \%$ & $\begin{array}{c}64,7 \\
\%\end{array}$ & $\begin{array}{c}66,7 \\
\%\end{array}$ & $35,7 \%$ & $92,3 \%$ \\
\hline 5 & & & & & * & $35,71 \%$ & $54,55 \%$ & $\begin{array}{c}70,27 \\
\%\end{array}$ & $\begin{array}{c}66,67 \\
\%\end{array}$ & $47,06 \%$ & $\begin{array}{c}70,27 \\
\%\end{array}$ \\
\hline 6 & & & & & & * & $52,63 \%$ & $\begin{array}{c}34,78 \\
\%\end{array}$ & $24 \%$ & $50 \%$ & $52,63 \%$ \\
\hline 7 & & & & & & & $*$ & $50 \%$ & $\begin{array}{c}33,33 \\
\%\end{array}$ & $64 \%$ & $64 \%$ \\
\hline 8 & & & & & & & & $*$ & $\begin{array}{c}70,59 \\
\%\end{array}$ & $34,4 \%$ & $\begin{array}{c}70,59 \\
\%\end{array}$ \\
\hline 9 & & & & & & & & & * & $38,71 \%$ & $38,71 \%$ \\
\hline 10 & & & & & & & & & & * & \\
\hline
\end{tabular}

Persentase terbesar tingkat kemiripan familia yang sama yaitu Acrididae. Selanjutnya tabel morfologi serangga dimiliki oleh spesies nomor 4 ini digunakan untuk mencari dan menentukan dan 5 dengan tingkat kemiripan 92,3\% (Tabel 3). spesies lain yang memiliki kekerabatan paling dekat Spesies nomor 4 adalah Melanoplus differentialis, dengan mereka dengan masih menggunakan rumus sedangkan spesies nomor 5 adalah Melanoplus indeks Sorensen (Tabel 4). Berikut adalah hasil bivitatus. Keduanya masih 1 genus dan berasal dari perhitungannya:

Tabel 4. Matriks tingkat kemiripan kelompok terbesar 1

\begin{tabular}{|c|c|c|c|c|c|c|c|c|c|}
\hline * & 4,5 & 1 & 2 & 3 & 6 & 7 & 8 & 9 & 10 \\
\hline 4,5 & * & $58,55 \%$ & $87,82 \%$ & $32,87 \%$ & $29,86 \%$ & $50,61 \%$ & $67,49 \%$ & $66,67 \%$ & $41,39 \%$ \\
\hline 1 & & * & $57,14 \%$ & $41,38 \%$ & $24 \%$ & $33,33 \%$ & $52,94 \%$ & $72,22 \%$ & $32,26 \%$ \\
\hline 2 & & & * & $35,70 \%$ & $25 \%$ & $48,3 \%$ & $54,5 \%$ & $62,9 \%$ & $40 \%$ \\
\hline 3 & & & & * & $44,4 \%$ & $43,5 \%$ & $14,8 \%$ & $41,4 \%$ & $66,7 \%$ \\
\hline 6 & & & & & * & $52,63 \%$ & $34,78 \%$ & $24 \%$ & $50 \%$ \\
\hline 7 & & & & & & * & $50 \%$ & $33,33 \%$ & $64 \%$ \\
\hline 8 & & & & & & & * & $70,59 \%$ & $34,48 \%$ \\
\hline 9 & & & & & & & & * & $38,71 \%$ \\
\hline 10 & & & & & & & & & $*$ \\
\hline
\end{tabular}

Angka yang dicetak tebal pada tabel diatas merupakan perolehan tertinggi pada matriks tersebut, yaitu sebesar 87,82\%. Angka tersebut dimiliki oleh spesies nomor 2 yang tidak lain adalah Valanga nigricornis dan masih merupakan anggota familia Acrididae.
Penghitungan tingkat kekerabatan spesies terus dilakukan sampai spesies terakhir. Tabel 5 sampai dengan 10 menunjukkan perolehan prosentase kemiripan yang sistematis, mulai dari yang terbesar sampai dengan yang terkecil. 
Tabel 5. Matriks tingkat kemiripan kelompok tebesar 2

\begin{tabular}{|c|c|c|c|c|c|c|c|c|}
\hline$*$ & $4,5,2$ & 1 & 3 & 6 & 7 & 8 & 9 & 10 \\
\hline $4,5,2$ & * & $58,08 \%$ & $33,82 \%$ & $28,24 \%$ & $49,83 \%$ & $63,17 \%$ & $65,40 \%$ & $40,92 \%$ \\
\hline 1 & & * & $41,38 \%$ & $24 \%$ & $33,33 \%$ & $52,94 \%$ & $72,22 \%$ & $32,26 \%$ \\
\hline 3 & & & * & $44,6 \%$ & $45,5 \%$ & $14,8 \%$ & $41,4 \%$ & $66,7 \%$ \\
\hline 6 & & & & * & $52,68 \%$ & $34,78 \%$ & $24 \%$ & $50 \%$ \\
\hline 7 & & & & & * & $50 \%$ & $33,33 \%$ & $64 \%$ \\
\hline 8 & & & & & & * & $70,59 \%$ & $34,48 \%$ \\
\hline 9 & & & & & & & * & $38,71 \%$ \\
\hline 10 & & & & & & & & * \\
\hline
\end{tabular}

Tabel 6. Matriks tingkat kemiripan kelompok tebesar 3

\begin{tabular}{|c|c|c|c|c|c|c|c|}
\hline * & $4,5,2$ & 1,9 & 3 & 6 & 7 & 8 & 10 \\
\hline $4,5,2$ & * & $61,74 \%$ & $33,82 \%$ & $28,24 \%$ & $49,83 \%$ & $63,17 \%$ & $65,40 \%$ \\
\hline 1,9 & & * & $41,38 \%$ & $24 \%$ & $33,33 \%$ & $61,75 \%$ & $35,48 \%$ \\
\hline 3 & & & * & $44,6 \%$ & $43,5 \%$ & $14,8 \%$ & $66,7 \%$ \\
\hline 6 & & & & * & $52,68 \%$ & $34,78 \%$ & $50 \%$ \\
\hline 7 & & & & & * & $50 \%$ & $64 \%$ \\
\hline 8 & & & & & & * & $34,48 \%$ \\
\hline 10 & & & & & & & * \\
\hline
\end{tabular}

Dalam satu familia yang sama tidak selalu hanya menunjukkan kemiripan 66,7\%. Prosentase memiliki kemiripan yang sangat tinggi (Tabel 6). ini lebih kecil jika dibandingkan spesies nomor 1 Spesies nomor 3 adalah Neoconocephalus ensiger dan dan 9 (Tabel 5) yang merupakan anggota familia spesies nomor 10 adalah Amblycoripha oblongifolia Acrididae yang memiliki kemiripan sebesar 72,22\%. yang merupakan familia Tettigonidae. Keduanya

Tabel 7. Matriks tingkat kemiripan kelompok tebesar 4

\begin{tabular}{ccccccc}
\hline$*$ & $\mathbf{4 , 5 , 2}$ & $\mathbf{1 , 9}$ & $\mathbf{3 , 1 0}$ & $\mathbf{6}$ & $\mathbf{7}$ & $\mathbf{8}$ \\
\hline $4,5,2$ & $*$ & $61,74 \%$ & $33,82 \%$ & $28,24 \%$ & $49,83 \%$ & $63,17 \%$ \\
1,9 & & $*$ & $38,43 \%$ & $24 \%$ & $33,33 \%$ & $61,75 \%$ \\
3,10 & & & $*$ & $47,22 \%$ & $53,74 \%$ & $24,65 \%$ \\
6 & & & & $*$ & $52,68 \%$ & $34,78 \%$ \\
7 & & & & & $*$ & $50 \%$ \\
8 & & & & & & $*$ \\
\hline
\end{tabular}

Spesies nomor 8 adalah Euthystira brachyptera familia Acrididae ternyata lebih dekat kekerabatnnya dengan Melanoplus differentialis, Melanoplus bivitatus dan Valanga nigricornis daripada dengan Gesonula mundata dan Acrida conica, dimana kelima spesies tersebut kesemuanya merupakan anggota familia Acrididae (Prakoso, 2017). 
Tabel 8. Matriks tingkat kemiripan kelompok tebesar 5

\begin{tabular}{cccccc}
\hline$*$ & $\mathbf{4 , 5 , 2 , 8}$ & $\mathbf{1 , 9}$ & $\mathbf{3 , 1 0}$ & $\mathbf{6}$ & $\mathbf{7}$ \\
\hline $4,5,2,8$ & $*$ & $61,74 \%$ & $34,19 \%$ & $29,87 \%$ & $49,87 \%$ \\
1,9 & & $*$ & $38,43 \%$ & $24 \%$ & $33,33 \%$ \\
3,10 & & & $*$ & $47,22 \%$ & $53,74 \%$ \\
6 & & & & $*$ & $52,68 \%$ \\
7 & & & & & $*$ \\
\hline
\end{tabular}

Tabel 9. Matriks tingkat kemiripan kelompok tebesar 6

\begin{tabular}{ccccc}
\hline$*$ & $\mathbf{4 , 5 , 2 , 8 , 1 , 9}$ & $\mathbf{3 , 1 0}$ & $\mathbf{6}$ & $\mathbf{7}$ \\
\hline $4,5,2,8,1,9$ & $*$ & $35,60 \%$ & $27,92 \%$ & $44,36 \%$ \\
3,10 & & $*$ & $47,22 \%$ & $53,74 \%$ \\
6 & & & $*$ & $52,68 \%$ \\
7 & & & & $*$ \\
\hline
\end{tabular}

Tabel 10. Matriks tingkat kemiripan kelompok tebesar 7

\begin{tabular}{cccc}
\hline$*$ & $\mathbf{4 , 5 , 2 , 8 , 1 , 9}$ & $\mathbf{3 , 1 0 , 7}$ & $\mathbf{6}$ \\
\hline $4,5,2,8,1,9$ & $*$ & $38,52 \%$ & $27,92 \%$ \\
$3,10,7$ & & $*$ & $49,03 \%$ \\
6 & & & $*$ \\
\hline
\end{tabular}

Tabel 11. Matriks tingkat kemiripan kelompok tebesar 8

\begin{tabular}{ccc}
\hline$*$ & $\mathbf{4 , 5 , 2 , 8 , 1 , 9}$ & $\mathbf{3 , 1 0 , 7 , 6}$ \\
\hline $4,5,2,8,1,9$ & $*$ & $35,87 \%$ \\
$3,10,7,6$ & & $*$ \\
\hline
\end{tabular}

Tabel 11 merupakan matriks terakhir yang menunjukkan hasil kekerabatan terjauh dari kesepuluh spesies yang diidentifikasi. Spesies nomor 6 memiliki perbedaan morfologi paling besar dibanding 9 spesies yang lain.

Tingkat kemiripan Neocurtila hexadactila dengan spesies acuan yaitu Melanoplus differentialis dan Melanoplus bivitatus hanya sebesar 35,87 \%. Hal ini dikarenakan Neocurtila hexadactila merupakan anggota familia Gryllotalpidea dengan jumlah sebaran yang cukup luas (Prakoso, 2017); (Riyanto, 2017).

\section{Persentase Kekerabatan Antar Spesies}

Dari 10 spesies yang telah dihitung indeks kemiripannya, selanjutnya diurutkan dari yang terbesar hingga terkecil. Tingkat kekerabatan antar spesies yang ditandai dengan besarnya prosentase kemiripan karakter morfologi (Tabel 12). Karakter morfologi merupakan salah satu hal penting dalam menentukan identifikasi dalam taksonomi (Morris, 2002). Bentuk atau karakter morfologi, secara umum memang merupakan data yang paling baik untuk membatasi suatu takson karena karakter morfologi mudah untuk dilihat dan bukan merupakan karakter yang tersembunyi. Selain itu, hasil penelitian dengan menggunakan karakter morfologi (karakter fenotip) seperti yang dilakukan dalam penelitian ini menunjukkan bahwa karakter morfologi sebagai bukti taksonomi baik digunakan untuk mengidentifikasi dan menganalisis tingkat kekerabatan ordo Orthoptera serta dapat mengetahui pengelompokannya (Khan \& Khamaludin, 2016). 
Tabel 12. Urutan terbesar berdasarkan Indeks Kesamaan

\begin{tabular}{llc}
\hline No & \multicolumn{1}{c}{ Identitas Spesies } & $\begin{array}{c}\text { Tingat } \\
\text { kemiripan }\end{array}$ \\
\hline 1 & $4: 5$ & $92,3 \%$ \\
2 & $4,5: 2$ & $87,82 \%$ \\
3 & $1: 9$ & $72,22 \%$ \\
4 & $4,5,2: 8$ & $63,17 \%$ \\
5 & $4,5,2,8: 1,9$ & $61,74 \%$ \\
6 & $3: 10$ & $66,7 \%$ \\
7 & $3,10: 7$ & $53,74 \%$ \\
8 & $36,10,7: 6$ & $49,03 \%$ \\
9 & $4,5,2,8,1,9: 3,10,7,6$ & $33,87 \%$ \\
\hline
\end{tabular}

\section{Simpulan}

Persentase kekerabatan paling dekat ditunjukkan oleh Melanoplus differentialis dan Melanoplus bivitatus yaitu sebesar 92,3\%. Secara sistematika kedua spesies tersebut berada pada satu genus dan familia yang sama yaitu Acrididae. Selain Acrididae, terdapat familia Tettigonidae yang diwakili oleh Neoconocephalus ensiger dan Amblycoripha oblongifolia. Kedua spesies tersebut menunjukkan kemiripan yang lebih kecil yaitu hanya sebesar $66,7 \%$ berdasarkan karakter morfologi yang dimiliki.

Spesies yang paling jauh kekerabatannya adalah Neocurtila hexadactila yang merupakan anggota familia Gryllotalpidea dengan tingkat kemiripan sebesar 33,87\%. Spesies dalam satu tingkatan takson yang sama cenderung memiliki kemiripan morfologi yang tinggi dibanding dengan spesies dari takson yang berbeda, meski beberapa spesies tidak menunjukkan hal demikian. Karakter morfologi dapat digunakan sebagai dasar klasifikasi spesies yang cukup relevan untuk setiap jenis dan jenjang suatu takson.

\section{Daftar Pustaka}

Bidau, C. J. (2014 ). Patterns in Orthoptera biodiversity. I. Adaptations in ecological and evolutionary contexts . Journal of Insect Biodiversity, Vol 2(20): 1-39.

Craig, D. B., \& Bock, J. H. (2009). Habitat relationships among grasshoppers (Orthoptera:Acrididae) at the Western Limit of the Great Plains in Colorado. American Midland Naturalist, 314-327.

Dinakaran, S., \& Anbalagan, S. (2007). Anthropogenic impacts on aquatic insects in six streams of south Western Ghats. Journal of Insect Science, Vol 7: article 37, hal 1-9.

Falahudin, I., Mareta, D. E., \& Rahayu, I. A. (2015). Diversitas Serangga Ordo Orthoptera pada Lahan Gambut di Kecamatan Lalan Kabupaten Musibanyuasin. Bioilmi, Vol. 1 No. 1 hal $1-7$.

Hojun Song, Ricardo Mariño-Pérez, A. Woller, D., \& Marta Cigliano, M. (2018). Evolution, Diversification, and Biogeography of Grasshoppers (Orthoptera: Acrididae). Insect Systematics and Diversity, Vol 2(4): 3; 1-25.

Horchkirch, A. (1996). Habitat Preferences of Grasshoppers (Orthoptera : Acridoidea, Eumastacoidea) in The East Usambara Mountains, Ne Tanzania, and Their Use for Bioindication. Ecotropica, Vol 2; hal 195-217.

Jayashree, H., \& Channaveerappa, H. (2016 ). Phygenetic Relationship of Six Species of Pyrgomorphidae (Orthoptera : Caelifera: Acridomorpha) as Revealed by RAPD - PCR Analisys. International Journal of Current Research, Vol. 8, Issue, 02, pp.26020-26026,.

Jordan, S. F., Mader, E. L., Hopwood, J., Baker, T. H., Cruz, J. K., Gill, K., .. . Vaughan, M. (2015). Beneficial Insect Habitat-Assessment Form and Guide. Portland, OR: The Xerces Society for Invertebrate Conservation.

Khan, N., \& Khamaludin, S. (2016). Identification od Ground Cricket (Orthoptera : Gryllidae : Nemobinae) With Reference to Their Sound Producing. FUUAST J. BIOL., Vol (2): 231236 . 
Lestari, D. F., Putri, R. D., Ridwan, M., \& Purwaningsih, A. D. (2015, September 5). Keanekaragaman kupu-kupu (Insekta: Lepidoptera) di Wana Wisata Alas Bromo, BKPH Lawu Utara, Karanganyar, Jawa Tengah. PROS SEM NAS MASY BIODIV INDON Vol 1, No 6, pp. 1284-1288.

Morris, S. J. (2002). Identification guide to grasshoppers (Orthoptera: Acrididae) in Central Otago and Mackenzie Country. New Zeland : New Zealand Department of Conservation.

Prakoso, B. (2017). Biodiversitas Belalang (Acrididae: ordo Orthoptera) pada Agroekosistem (zea mays 1.) dan Ekosistem Hutan Tanaman di Kebun Raya Baturaden, Banyumas. Biosfera Vol 34, No 2 Mei 2017 : 80-88, Vol 34, No 2 : 80-88.

Riyanto. (2017). Keanekeragaman Belalang Ordo Orthoptera di Tepian Sungai Musi Palembang sebagai Materi Kuliah Entomologi di Pendidikan Biologi Fakultas Keguruan dan Ilmu Pendidikan Universitas Sriwijaya. Jurnal Pembelajaran Biologi, Volume 4, No. 1, Hal .

Wrueng, P. D., Tan, M. K., Artchawakom, T., \& Waengsothorn, S. (2017). Species Checklist of Orthoptera (Insecta) from Sakaerat Environmental Research Station, Thailand (Southeast Asia). Zootaxa, Vol $3: 301-324$.

\section{Diagram Dendogr}

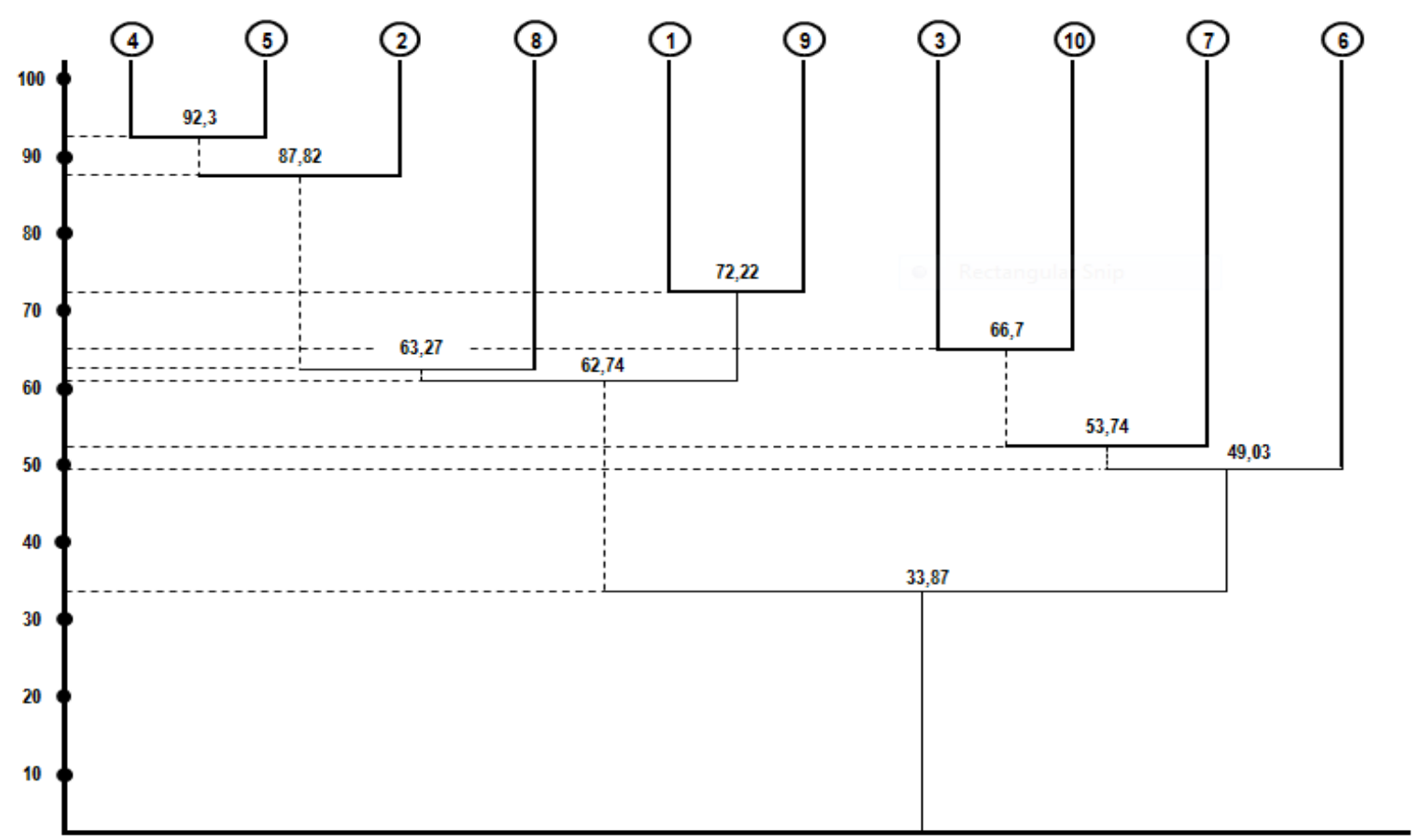

